\title{
A microbiological study of Papillon-Lefèvre syndrome in two patients
}

\author{
K L Robertson, D B Drucker, J James, A S Blinkhorn, S Hamlet, P S Bird
}

\begin{abstract}
Aim-To analyse the microflora of subgingival plaque from patients with PapillonLefèvre syndrome (PLS), which is a very rare disease characterised by palmarplantar hyperkeratosis with precocious periodontal destruction.
\end{abstract}

Methods-Bacterial isolates were identified using a combination of commercial identification kits, traditional laboratory tests, and gas liquid chromatography. Some isolates were also subjected to partial 16S rDNA sequencing. Plaque samples were also assayed for the presence of Porphyromonas gingivalis, Prevotella intermedia, and Actinobacillus actinomycetemcomitans in a quantitative enzyme linked immunosorbent assay (ELISA) using monoclonal antibodies. Results-The culture results showed that most isolates were capnophilic and facultatively anaerobic species-mainly Capnocytophaga spp and Streptococcus spp. The latter included $S$ constellatus, $S$ oralis, and $S$ sanguis. Other facultative bacteria belonged to the genera gemella, kingella, leuconostoc, and stomatococcus. The aerobic bacteria isolated were species of neisseria and bacillus. Anaerobic species included Prevotella intermedia, $P$ melaninogenica, and $P$ nigrescens, as well as Peptostreptococcus spp. ELISA detected $\boldsymbol{P}$ gingivalis in one patient in all sites sampled, whereas $A$ actinomycetemcomitans was detected in only one site from the other patient. Prevotella intermedia was present in low numbers.

Conclusions-Patients with PLS have a very complex subgingival flora including recognised periodontal pathogens. However, no particular periodontopathogen is invariably associated with PLS.

(f Clin Pathol 2001;54:371-376)

Laboratory, University of Manchester Dental School, Higher

Cambridge Street,

Manchester M15 6FH,

UK

K L Robertson

J James

A S Blinkhorn

D B Drucker

University of

Queensland School of

Dentistry, Brisbane

Q1d 4072, Australia

$S$ Hamlet

P S Bird

Correspondence to: Dr Drucker

David.Drucker@man.ac.uk

Accepted for publication 20 November 2000

Keywords: Papillon-Lefèvre syndrome;

periodontopathogens

Papillon-Lefèvre syndrome (PLS) was first described in 1924 by Papillon and Lefevre. ${ }^{1}$ It is a rare autosomal recessive disease, ${ }^{2}$ with an incidence of 1-4 cases/million people, ${ }^{3}$ and with consanguinity between parents seen in one third of cases. ${ }^{4}$ The disease is characterised by palmar-plantar hyperkeratosis, a thickening of the skin on the palms of the hands and the soles of the feet. ${ }^{5}$ In addition, precocious periodontal destruction of both the deciduous and permanent teeth is seen. ${ }^{6}$ The gingiva become red and inflamed and may be ulcerated ${ }^{5}$ and a form of rapid, severe periodontitis occurs. ${ }^{4}$ Alveolar bone is resorbed and deep periodontal pockets form leading to increased tooth mobility. ${ }^{6}$ Usually, both deciduous teeth ${ }^{7}$ and permanent teeth ${ }^{6}$ are lost prematurely.

PLS is a systemic disease with immune system defects, ${ }^{8}$ which might result in the proliferation of certain periodontopathogens. Microbiological studies of the oral microflora of patients with PLS have shown that the predominant organisms in the periodontal sites are Gram negative anaerobic rods, ${ }^{9}$ including Porphyromonas gingivalis, Prevotella intermedia, Prevotella loescheii, Bacteroides gracilis, ${ }^{10}$ and Fusobacterium nucleatum. ${ }^{10} 11$ Eikenella corrodens, capnocytophaga, ${ }^{11}$ veillonella, anaerobic streptococci, ${ }^{12}$ and spirochaetes have also been reported. ${ }^{13}{ }^{14}$ Although the presence of cultivatable Actinobacillus actinomycetemcomitans and raised serum antibody titres to $A$ actinomycetemcomitans have been found, ${ }^{10} 12131516$ this is not always the case. ${ }^{11} 17$

The aims of our study were to identify the subgingival plaque microflora of two patients with PLS and to assess the amounts of the periodontopathic bacteria, $A$ actinomycetemcomitans, $P$ gingivalis, and $P$ intermedia using a quantitative enzyme linked immunosorbent assay (ELISA).

\section{Methods}

\section{PLAQUE SAMPLES}

Two patients with PLS attended the University of Manchester Dental Hospital. Patient 1 had only six teeth remaining and subgingival plaque samples were taken from each tooth. A further five subgingival plaque samples were also collected from the molars and canine teeth of patient 2. All samples were collected with a curette and (1) placed into reduced transport fluid for rapid transportation to Manchester Royal Infirmary for initial bacterial cultivation; (2) resuspended in phosphate buffered saline (PBS) containing $0.01 \%$ thiomersal, frozen, and sent to the University of Queensland, St Lucia, Australia for analysis with specific monoclonal antibodies by means of ELISA.
ENZYME LINKED IMMUNOSORBENT ASSAY

Plaque samples were thawed, six to eight $1 \mathrm{~mm}$ glass beads added to each vial, and the bacteria dispersed by vortexing and then sonicated for five seconds. Samples were diluted in an equal volume of $0.1 \mathrm{M}$ carbonate buffer $\mathrm{pH}$ 9.6. A $100 \mu \mathrm{l}$ volume of each sample was pipetted into triplicate wells of a 96 well Maxisorp microtitre plate (Nunc, Roskilde, Denmark). A known concentration of bacterial cells of either $A$ actinomycetemcomitans $\mathrm{Y} 4, P$ gingivalis FDC381 , or P intermedia ATCC 25611 (ranging from 9 to $150 \times 10^{4}$ cells $/ \mathrm{ml}$ ) in carbonate buffer were assayed on each plate with the 
plaque samples. Microtitre plates were incubated overnight at $4^{\circ} \mathrm{C}$ and washed three times with PBS/Tween 20 (0.05\%; PBS-T). Nonspecific binding was blocked with PBS-T containing $1 \%$ fetal calf serum (Commonwealth Serum Laboratory, Melbourne, Australia) and the plates were incubated for one hour at room temperature (RT). After washing $(\times 3)$ with PBS-T, diluted horseradish peroxidase labelled monoclonal antibodies specific to either $A$ actinomycetemcomitans, $P$ gingivalis, or $P$ intermedia were added to all the coated wells and incubated for two hours at RT. After further washing $(\times 3)$ with PBS-T, colour development was achieved by adding $150 \mu \mathrm{l}$ of $2.5 \mathrm{mM}$ $\sigma$-tolidine (Kodak Eastman, Rochester, New York, USA) in $100 \mathrm{mM}$ phosphate citrate buffer ( $\mathrm{pH}$ 3.5) containing $0.025 \mathrm{mM}$ EDTA and activated by $3 \% \quad \mathrm{H}_{2} \mathrm{O}_{2}$. The colour development was stopped after 10 minutes by the addition of $50 \mu \mathrm{l}$ of $1 \mathrm{M} \mathrm{HCl}$. The plates were read in a Bio-Rad microplate reader model 3550 (Bio-Rad Laboratories, Hercules, California, USA) at $450 \mathrm{~nm}$ and $655 \mathrm{~nm}$.

\section{DETECTION OF SPIROCHAETES}

Smears were prepared from the plaque samples, air dried, and stained with a modified Gram stain, where the counter stain was $20 \%$ carbol fuchsin, applied for five minutes. Slides were viewed under a Zeiss (Jena, Germany), Axioplan light microscope at $\times 1000$ magnification.

CULTIVATION OF PLAQUE SAMPLES

Plaque samples were plated on to Columbia blood agar plates supplemented with 5\% defibrinated horse blood (Oxoid, Basingstoke, UK) and fastidious anaerobe agar (FAA; Lab $\mathrm{M}$, Bury, UK) plates supplemented with $5 \%$ defibrinated horse blood (Oxoid). Columbia agar plates were incubated in an aerobic atmosphere for three days at $37^{\circ} \mathrm{C}$. The latter were incubated in a Compact $M$ anaerobic cabinet (Don Whitley Scientific, Shipley, UK) in an atmosphere of $10 \%$ hydrogen, $10 \%$ carbon dioxide, and $80 \%$ nitrogen for three to five days at $37^{\circ} \mathrm{C}$. Selected isolated colonies were subcultured.

IDENTIFICATION OF ISOLATES

Plaque contains many species; thus, we selected the predominant organisms for further study. All isolates were Gram stained and tested for catalase, oxidase activity, aerobic growth, and anaerobic growth. In some cases, other tests were used such as Hugh and Leifson's oxidation fermentation test, nitrate reduction, extracellular polysaccharide production on TYC agar, and spore production. Isolates were identified using a range of commercial identification kits, namely: API 20 NE; Rapid ID 32 Strep; API Coryne; Rapid ID 32A (BioMérieux, Basingstoke, Hampshire, UK), and the Rapid ANA II system (Prolab, Liverpool, UK). Microcodes generated using API 20 NE, ID 32 Strep, API Coryne, or ID 32A were analysed by BioMérieux. Microcodes generated using Rapid ANA II were analysed by Prolab. Anaerobe identification also made use of schemes in the Wadsworth anaerobic bacteriology manual and Virginia Polytechnic Institute anaerobe laboratory manual. ${ }^{18}{ }^{19}$ Bacterial culture supernatants from Gram positive bacteria were analysed for the presence of non-volatile acids. ${ }^{18}$ For gas chromatographic analysis of end products, established methods were followed, ${ }^{18}$ except that supernatant fluid from 48 hour gas liquid chromatography (GLC) broth (Lab M) cultures was used. Samples $(2 \mu \mathrm{l})$ were analysed on a column of $6 \%$ Carbowax 20M TPA on Chromosorb W AWDMCS (Phase Separations, Queensferry, UK), whether ether extracts of volatile end products or chloroform extracts of methylated non-volatile acids. The injector and detector temperatures of the chromatograph (AI, Cambridge, UK) were both $150^{\circ} \mathrm{C}$. The initial temperature of the column was $65^{\circ} \mathrm{C}$, which was held for 30 seconds before being increased linearly to $115^{\circ} \mathrm{C}$ over two minutes, and held for six minutes and 20 seconds. The equilibration time between samples was three minutes.

When satisfactory identification could not be achieved, the partial sequence of the $16 \mathrm{~S} \mathrm{rRNA}$ gene was determined and compared with library data for known organisms.

DNA EXTRACTION: GRAM NEGATIVE BACTERIA

Bacterial isolates were grown to purity on FAA. Isolated colonies were subcultured into fastidious anaerobe broth and DNA was extracted from a 72 hour culture. Briefly, $5 \mathrm{ml}$ of each bacterial culture was centrifuged at $3000 \times g$ for 10 minutes and the cells resuspended in sucrose/Tris/EDTA (STE). Lysozyme (Sigma, Poole, Dorset, UK) was added to give a final concentration of $2 \mathrm{mg} / \mathrm{ml}$ and incubated at $37^{\circ} \mathrm{C}$ for 30 minutes. Proteinase $\mathrm{K}(0.3 \mathrm{mg} / \mathrm{ml})$ and sodium dodecyl sulphate (SDS; $1 \%$ final concentration) were added and incubated at $55^{\circ} \mathrm{C}$ for one hour, to induce cell lysis. An equal volume of phenol/chloroform/isoamyl alcohol (25/24/1, vol/vol/vol) was added to each suspension and vortexed. After centrifugation at $16000 \times g$ for 10 minutes, $24 \mu \mathrm{l} 5 \mathrm{M} \mathrm{NaCl}$ and $600 \mu \mathrm{l}$ propan-2-ol were added. Gentle mixing and incubation at $0^{\circ} \mathrm{C}$ for 10 minutes were followed by centrifugation at $16000 \times g$ for 10 minutes. The pellet was resuspended in water and one volume of ammonium acetate was added (final concentration of $2.5 \mathrm{M}$ ). The suspension was then cooled at $0^{\circ} \mathrm{C}$ for one hour then centrifuged at $16000 \times g$ for 20 minutes. The supernatant was removed and the DNA was reprecipitated by the addition of $600 \mu \mathrm{l}$ of chilled ethanol $\left(-85^{\circ} \mathrm{C}\right)$. The DNA was pelleted by centrifugation at $16000 \times g$ for 10 minutes and then washed in $500 \mu 170 \%$ chilled ethanol $\left(-85^{\circ} \mathrm{C}\right)$. The ethanol was removed and the DNA was resuspended in $100 \mu \mathrm{l}$ Tris/ EDTA (TE) and stored at $4^{\circ} \mathrm{C}$.

DNA EXTRACTION: GRAM POSITIVE BACTERIA DNA was extracted from all Gram positive clinical isolates using the Puregene DNA isolation kit (Flowgen Instruments, Staffordshire, UK), according to the manufacturer's instructions. 
MEASUREMENT OF DNA

Samples $(5 \mu \mathrm{l})$ of DNA were stained with ethidium bromide $\left(1 \mu \mathrm{g} \mathrm{ml}^{-1}\right.$ in $1 \times$ trisphosphate EDTA (TPE)) after electrophoresis in an $0.8 \%$ agarose gel and then visualised by ultraviolet light $(\lambda=254 \mathrm{~nm})$ and photographed on Polaroid 667 film. The amount of DNA was determined by visual comparison with known amounts of uncut $\lambda$ DNA (Sigma; 40-400 ng $\mu^{-1}$ ).

PARTIAL 16S rRNA GENE SEQUENCE ANALYSIS Bacterial DNA was amplified in a Crocodile IIJ thermal cycler (Appligene, County Durham, UK). The reaction mix (total volume, $50 \mu \mathrm{l}$ ) consisted of $2 \mu \mathrm{l}$ of DNA, Taq polymerase (1.5 units), $0.2 \mathrm{mM}$ of each deoxynucleoside triphosphate (dATP, dCTP, dGTP, dTTP), $\mathrm{MgCl}_{2}(1.5 \mathrm{mM}), 1 \times$ buffer IV, and $0.3 \mu \mathrm{M}$ of both primers: RE-TPU1 (5'-AGA GTTTGATCMTGGCTCAG) and RERTU3 (5'-GWATTACCGCGGCKGCG) ${ }^{20}$ (Oligonucleotide Synthesising Service, School of Biological Sciences, University of Manchester, UK). The reaction mix was covered with an equal volume $(20 \mu \mathrm{l})$ of mineral oil to prevent evaporation. Negative controls contained all components of the reaction mix except the bacterial template DNA. The thermal cycling profile was as follows: one cycle of four minutes at $94^{\circ} \mathrm{C}$, one minute at $55^{\circ} \mathrm{C}$, one minute at $72^{\circ} \mathrm{C}$; 29 cycles of one minute at $94^{\circ} \mathrm{C}$, one minute at $57^{\circ} \mathrm{C}$, one minute at $72^{\circ} \mathrm{C}$; one cycle of one minute at $94^{\circ} \mathrm{C}$, one minute at $57^{\circ} \mathrm{C}$, and five minutes at $72^{\circ} \mathrm{C}$. Polymerase chain reaction $(\mathrm{PCR})$ products $(3 \mu \mathrm{l})$ were resolved in $1.0 \%$ agarose gels, stained with ethidium bromide, and visualised under ultraviolet light $(\lambda=254 \mathrm{~nm})$. A $\lambda$ Pst1 digest was used as a size marker $(270 \mathrm{ng} / \mu \mathrm{l})$. Gels were photographed on Polaroid 665 and 667 films and the presence of the correct size fragment confirmed. QIAquick PCR purification kit (Qiagen, Crawley, Sussex, UK) was used to clean the PCR product. The quantity of the product was estimated by visual comparison in a $0.8 \%$ agarose gel with a known amount of $\lambda$ DNA. Concentrations of PCR products $(30-90 \mathrm{ng}$ ) were amplified further in a Perkin Elmer (Warrington, UK) model 2400 thermal cycler. Two reaction mixes were set up for each PCR product, one with each primer. The reaction mix had a total volume of $20 \mu \mathrm{l}$, which consisted of $8 \mu \mathrm{l}$ ABI PRISM ${ }^{\mathrm{TM}}$ terminator cycle sequence ready reaction mix (Perkin Elmer) or $4 \mu \mathrm{l}$ ABI PRISM ${ }^{\mathrm{TM}}$ BigDye $^{\mathrm{TM}}$ terminator cycle sequence ready reaction mix (Perkin Elmer) and either RE-RTU3 or RE-TPU1 $(0.15 \mu \mathrm{M})$. The PCR product was added and the volume made up with water. The thermal cycling profile was as follows: 25 cycles of 10 seconds at $96^{\circ} \mathrm{C}$, five seconds at $50^{\circ} \mathrm{C}$, and four minutes at $60^{\circ} \mathrm{C}$. The cycle sequencing product was purified by ethanol precipitation. The automated sequence analysis was performed by Oswals DNA Service, University of Southampton. Sequences were manipulated using the Genetics Computer Group (GCG) package version 8.0 (Wisconsin, USA).
Sequences resulting from amplification with primer RE-RTU3 were reverse transcribed and changed to the complement. Results from each primer were then aligned using GAP function and checked twice against each other to produce a consensus sequence. The consensus sequence was submitted for a FASTA search to determine the most likely relation.

\section{Results}

A total of 108 pure cultures of predominant organisms was obtained for identification and comprised the genera and species listed in tables 1-3. The bacterial species isolated (including those determined by ELISA) were separated into aerobic, anaerobic, facultative, and capnophilic species and 17 genera were found to be present. The facultative microorganisms identified consisted mainly of species of streptococcus, including Streptococcus anginosus, $S$ bovis, $S$ constellatus, $S$ mitis, and $S$ sanguis. Species of capnocytophaga and gemella were also identified. The obligately anaerobic flora consisted mostly of prevotella species, namely: Prevotella intermedia, $P$ nigrescens, P melaninogenica, and "unidentified" prevotella (formerly "PINLO"). In addition, Peptostreptococcus anaerobius, Pstr micros and species of mobiluncus were identified. Table 1 gives a comprehensive list of species cultured for each patient. Gemella spp, Neisseria spp,

Table 1 Complete list of bacterial species isolated from two patients with Papillon-Lefèvre syndrome, displaying association with patient

\begin{tabular}{|c|c|c|}
\hline & Patient 1 & Patient 2 \\
\hline \multicolumn{3}{|l|}{ Obligate aerobes } \\
\hline Neisseria $\mathrm{sp}$ & 2 & 0 \\
\hline$N$ cinerea & 1 & 1 \\
\hline$N$ elongata & 0 & 1 \\
\hline$N$ flavescens & 0 & 2 \\
\hline Neisseria sp possibly $N$ subflava & 1 & 0 \\
\hline \multicolumn{3}{|l|}{ Obligate anaerobes } \\
\hline Eubacterium $\mathrm{sp}$ & 0 & 1 \\
\hline Porphyromonas gingivalis & 1 & 0 \\
\hline Prevotella sp possibly $P$ oralis & 1 & 0 \\
\hline P intermedia & 1 & 1 \\
\hline P melaninogenica & 0 & 2 \\
\hline P nigrescens & 0 & 2 \\
\hline Peptostreptococcus $\mathrm{sp}$ & 1 & 0 \\
\hline Pstr anaerobius & 0 & 1 \\
\hline Pstr micros & 1 & 0 \\
\hline \multicolumn{3}{|l|}{ Facultative } \\
\hline Actinobacillus actinomycetemcomitans & 0 & 1 \\
\hline Actinomyces sp & 1 & 0 \\
\hline A israelii & 1 & 0 \\
\hline Bacillus cereus & 1 & 0 \\
\hline Gemella haemolysans & 1 & 0 \\
\hline G morbillorum & 1 & 1 \\
\hline Kingella denitrificans & 1 & 0 \\
\hline Leuconostoc $\mathrm{sp}$ & 0 & 1 \\
\hline$L$ mesenteroides & 0 & 1 \\
\hline Mobiluncus sp & 1 & 0 \\
\hline Streptococcus sp (to genus only) & 1 & 1 \\
\hline$S$ anginosus & 0 & 2 \\
\hline$S$ bovis II & 1 & 0 \\
\hline$S$ constellatus & 3 & 0 \\
\hline$S$ gordonii & 0 & 1 \\
\hline$S$ intermedius & 0 & 1 \\
\hline$S$ milleri group & 1 & 1 \\
\hline$S$ mitis & 2 & 1 \\
\hline Soralis & 1 & 0 \\
\hline$S$ salivarius subspecies $P$ salivarius & 1 & 1 \\
\hline$S$ sanguis & 3 & 1 \\
\hline Stomatococcus mucilaginosus & 1 & 0 \\
\hline Suttonella indologenes & 1 & 0 \\
\hline \multicolumn{3}{|l|}{ Capnophilic } \\
\hline Capnocytophaga $\mathrm{sp}$ & 1 & 0 \\
\hline
\end{tabular}

The numbers refer to the total number of sites with the isolate. 
Table 2 Predominant species isolated from patient 1 according to site sampled

\begin{tabular}{|c|c|}
\hline \multicolumn{2}{|c|}{ Site A (upper right deciduous canine) } \\
\hline Actinomyces sp & Peptostreptococcus sp \\
\hline Bacillus cereus & Prevotella sp \\
\hline Capnocytophaga sp & Streptococcus constellatus \\
\hline Kingella denitrificans & $S$ mitis \\
\hline Neisseria cinerea & $S$ sanguis \\
\hline Neisseria sp & Streptococcus sp \\
\hline \multicolumn{2}{|c|}{ Site B (lower left deciduous canine) } \\
\hline Actinomyces israelii & $S$ milleri group \\
\hline Mobiluncus sp & Soralis \\
\hline Neisseria $\mathrm{sp}$ & $S$ sanguis \\
\hline Streptococcus constellatus & \\
\hline \multicolumn{2}{|c|}{ Site C (upper left deciduous 1st molar) } \\
\hline Streptococcus bovis II & Stomatococcus mucilaginosus \\
\hline$S$ constellatus & Neisseria subflava \\
\hline S sanguis & \\
\hline \multicolumn{2}{|c|}{ Site D (lower left deciduous 1st molar) } \\
\hline Gemella haemolysans & Peptostreptococcus micros \\
\hline G morbillorum & Streptococcus sanguis \\
\hline Prevotella intermedia & \\
\hline \multicolumn{2}{|c|}{ Site E (lower right deciduous canine) } \\
\hline $\begin{array}{l}\text { Suttonella indologenes } \\
\text { Actinomyces meyeri }\end{array}$ & Capnocytophaga sp \\
\hline $\begin{array}{l}\text { Actinomyces meyeri } \\
\text { Site F (lower right deciduou }\end{array}$ & \\
\hline \multicolumn{2}{|c|}{ Site F (lower right deciduous 1st molar) } \\
\hline \multicolumn{2}{|c|}{$\begin{array}{l}\text { Table } 3 \text { Predominant species isolated from patient } 2 \\
\text { separated according to site of sample }\end{array}$} \\
\hline \multicolumn{2}{|c|}{ Site A (upper right permanent 1 st molar) } \\
\hline Eubacterium $\mathrm{sp}$ & $P$ nigrescens \\
\hline Leuconostoc sp & Peptostreptococcus anaerobius \\
\hline Neisseria cinerea & $S$ anginosus \\
\hline N elongata & $S$ intermedius \\
\hline N flavescens & $S$ salivarius subspecies savlivarius \\
\hline Prevotella melaninogenica & Actinomyces meyeri \\
\hline Streptococcus sanguis & \\
\hline \multicolumn{2}{|c|}{ Site B (upper right permanent canine) } \\
\hline P melaninogenica & $S$ milleri group \\
\hline P nigrescens & $S$ mitis \\
\hline Streptococcus gordonii & Streptococcus sp \\
\hline \multicolumn{2}{|c|}{ Site C (lower right permanent canine) } \\
\hline \multirow{2}{*}{\multicolumn{2}{|c|}{$\begin{array}{l}\text { Leuconostoc mesenteroides } \\
\text { Site D (lower left canine) }\end{array}$}} \\
\hline \multirow{2}{*}{\multicolumn{2}{|c|}{$\begin{array}{l}\text { Site D (lower left canine) } \\
\text { Peptostreptococcus micros }\end{array}$}} \\
\hline & \\
\hline \multicolumn{2}{|l|}{ Site E (lower left first molar) } \\
\hline Actinomyces meyeri & \\
\hline
\end{tabular}

Peptostreptococcus spp, P intermedia, and Streptococcus spp were isolated from both patients. Actinomyces spp, Bacillus spp, Capnocytophaga spp, Kingella spp, Mobiluncus spp, P gingivalis, and Stomatococcus spp were isolated only from patient 1, whereas $A$ actinomycetemcomitans, Eubacterium spp, Leuconostoc spp, P nigrescens, and $P$ melaninogenica were isolated only from patient 2. Tables 2 and 3 show the correlation between the species identified and the site sampled in the patients.

Culture provided qualitative data only. However, monoclonal antibodies provided quantitative data and detected $P$ gingivalis in low numbers in all six sites sampled in patient 1 ; $A$ actinomycetemcomitans was detected in one site in low numbers in patient 2. Prevotella intermedia was detected in low numbers from both patients - in one of six sites from patient 1 and three of six sites from patient 2 .

The occurrence of spirochaetes in the plaque was confirmed by microscopy.

\section{Discussion}

A range of bacteria was found in the subgingival plaque of both these patients with PLS. In addition, the periodontopathic bacteria $P$ gingivalis, $P$ intermedia, and $A$ actinomycetemcomitans were detected, albeit in low numbers.
"Control" sites were not studied because in the case of severe PLS there are no healthy control sites.

Aerobes identified were species of bacillus and neisseria. The Gram positive, spore former Bacillus cereus is not considered part of the normal oral flora, although it has been reported in plaque samples. ${ }^{20}$ With no reports of an association with periodontal disease and because of its universal occurrence and the formation of spores, the possibility that this is a contaminant cannot be ruled out. Neisseria spp- $N$ siccal subflava $^{10}$ and $N$ pharyngis ${ }^{21}$ - have been reported previously in other patients with PLS. In our study, the identification of isolates as either species of neisseria or prevotella was second only to identification as streptococcus.

Five genera of obligately anaerobic bacteria were identified-eubacterium, peptostreptococcus, porphyromonas, prevotella, and treponema. Species of eubacterium have been isolated from subgingival plaque ${ }^{22}$ and are associated with oral health, gingivitis, ${ }^{23}$ and periodontal disease in humans, ${ }^{24}{ }^{25}$ although little evidence is available for an association with PLS. One study ${ }^{13}$ has failed to isolate eubacterium from plaque samples despite the use of selective media, although low numbers were cultured from mouth rinse samples, suggesting that eubacterium was present in the oral cavity of patients with PLS. Unidentified Peptostreptococcus spp have been isolated from the subgingival plaque of patients with periodontal disease ${ }^{25}$ and Pstr micros has been associated with gingivitis. ${ }^{23}$ Peptostreptococcus micros $^{10}$ and unspeciated peptococcaceae ${ }^{13}$ have also been identified previously from patients with PLS.

Porphyromonas gingivalis is an accepted periodontal pathogen, ${ }^{26}{ }^{27}$ which was detected by monoclonal antibodies in one of the patients. The use of monoclonal antibodies to $P$ gingivalis in a previous study ${ }^{10}$ detected this species in one of the two patients. It has also been isolated previously from patients with PLS using culture methods. ${ }^{10}{ }^{13}$

Prevotella intermedia, P melaninogenica, P nigrescens, and $P$ oralis were identified in our present study. Prevotella oralis, P oris, Ploeschii, ${ }^{10} P$ intermedia, ${ }^{10}{ }^{13}$ and other unspeciated black pigmented anaerobes ${ }^{913} 17$ have been associated previously with PLS. In earlier studies, $P$ nigrescens was probably misidentified as P intermedia. Prevotella melaninogenica has not been isolated previously from PLS samples but it occurs in subgingival plaque ${ }^{28}$ and has been associated with gingivitis ${ }^{26}$ and periodontal disease $^{29}$. Prevotella intermedia was detected both by culture and ELISA in our study, methods by which it has previously been detected in PLS. ${ }^{10}$

Unspeciated spirochaetes were seen within gingival smears during our study and have been reported previously in patients with PLS. ${ }^{13}{ }^{14}$

Actinobacillus actinomycetemcomitans is an accepted periodontopathogen, ${ }^{23}{ }^{27}{ }^{30}$ which has been associated particularly with prepubertal periodontitis $^{31}$ and localised juvenile periodontitis. ${ }^{32}$ It has been associated with PLS on many occasions ${ }^{1012131516}$ and is considered an important pathogen for the periodontal component 
of PLS. ${ }^{32}$ We detected this organism using monoclonal antibodies, but only in one sample from patient 2. Therefore, the presence of $A$ actinomycetemcomitans might not be necessary for PLS to progress. This argument could also apply to $P$ gingivalis, which was only detected in patient 1 .

We identified three actinomyces species that have been associated with PLS previously. ${ }^{10}$ Actinomyces spp form part of the resident oral microflora of humans ${ }^{33}$ and are therefore isolated from the healthy oral cavity and associated with gingivitis. ${ }^{23}$

Gemella morbillorum has been isolated previously from patients with PLS and is also associated with a healthy mouth, ${ }^{23}$ whereas no association with periodontal disease or PLS has been reported for G haemolysans. The likelihood of gemella causing similar infections to those caused by viridans streptococci has been noted, ${ }^{34}$ so that the isolation of this microorganism from patients with PLS is not surprising.

Kingella species include known upper respiratory tract commensals ${ }^{35}$; however, there are no reports of the isolation of members of this genus from patients with PLS and only limited associations with periodontal disease. The primary habitat of $K$ oralis is human dental plaque and it been isolated from supragingival and subgingival plaque taken both from healthy oral cavities and patients with periodontitis. ${ }^{36}$

The genus leuconostoc contains species similar to streptococci and often identified initially as $S$ sanguis type II as well as $S$ salivarius and $S$ pneumoniae, when using automated identification systems. ${ }^{37}$ Leuconostoc has not been previously identified in PLS samples. However, this genus has been reported to be a cause of bacteraemia in patients already critically ill with acute leukaemia, renal failure, and human immunodeficiency virus infection. ${ }^{37}$ It has been suggested that the incorrect identification of leuconostoc as viridans streptococci means that the pathogenic associations of this genus have been underestimated. ${ }^{37}$ During our study, both viridans streptococci ( $S$ constellatus, $S$ mitis, $S$ oralis, and $S$ sanguis) and $S$ salivarius were identified using Rapid ID 32 Strep; however, additional testing would be required to check that none of these isolates was a species of leuconostoc. ${ }^{37}$ Of the ten streptococcal species identified here, $S$ bovis, $S$ mitis, "S milleri group", and $S$ sanguis ${ }^{10}$ have been associated with PLS previously; other studies $^{12}{ }^{13}$ have detected streptococci but not identified them further. Previously, $S$ oralis has been associated with gingivitis. ${ }^{23}$

One isolate was identified as Stomatococcus mucilaginosus, an organism found within the oral microflora, ${ }^{38}$ although it has not been previously associated with the periodontal flora in PLS. The variable catalase reaction can delay identification and cause confusion with staphylococcal and streptococcal species, which has led to the underestimation of its prevalence.

Mobiluncus has been isolated from extravaginal sources ${ }^{39}$ other than the mouth. This organism may have been misidentified as actinomyces because of a positive Gram reaction and a similar GLC profile.

Members of the genus capnocytophaga have been frequently associated with gingivitis, ${ }^{23}$ periodontal disease, ${ }^{27}$ and juvenile periodontitis. ${ }^{29}$ Species of this organism have been reported in patients with PLS. ${ }^{10}{ }^{11}$ Capnocytohaga ochracea ${ }^{10}$ has been isolated, but most studies have identified isolates only to the genus level. Paradoxically, capnocytophaga has also been found to be associated negatively with periodontal disease. ${ }^{40}$

Species not isolated here but reported in other studies ${ }^{1011}{ }^{13}$ include Fusobacterium spp, Eikenella corrodens, veillonella, and Bacillus gracilis. The recognised periodontal pathogens $P$ gingivalis and $A$ actinomycetemcomitans were found in low numbers in our patients with PLS. It is possible that $A$ actinomycetemcomitans acts together with human herpesviruses in the development of the syndrome, ${ }^{41}$ but our present study did not include virological examination. Furthermore, a "massive occurrence of $A$ actinomycetemcomitans" has been noted in periodontal pockets in PLS, although the same species was present also in the mouths of siblings and a parent without PLS. ${ }^{42}$ Similarly, in a group of 12 Saudi-Arabian adolescents with PLS, there was no PLS specific profile of the subgingival infection because the bacterial composition resembled that characterising deep pockets in adult patients with periodontitis. ${ }^{43}$ It is possible that recognised periodontal pathogens might be involved in PLS. However, the severity of periodontitis in patients with PLS cannot be explained simply by the presence of any of the bacteria found in this study, even the recognised periodontopathogens. These patients are known to have a higher risk of developing disease when compared with other individuals, suggesting that host factors determine the individual's disease susceptibility. The inherited components of PLS induce both immune and epithelial defects. ${ }^{41}$ We conclude that PLS occurs in genetically susceptible individuals whose periodontal disease is associated with periodontal pathogens but the species of periodontopathogen is not of overriding importance.

Thanks to M Armstrong at the Manchester Royal Infirmary for initial cultivation of samples.

1 Papillon MM, Lefevre P. Deux cas de kératodermie palmaire et plantaire symétrique familiale (maladie de Meleda) chez le frère et la soeur. Coexistence dans leux deux cas d'altérations dentaires graves. Bulletin de Société de Dermatologie et de Syphiligraphie 1924;31:82-7.

2 Griffiths WAD, Leigh IM, Marks R. Papillon-Lefèvre Griffiths WAD, Leigh IM, Marks R. Papillon-Lefevre
syndrome. In: Champion RH, Burton JL, Ebling FJG, eds. syndrome. In: Champion RH, Burton JL, Ebling FJG, eds.
Textbook of dermatology, 5th ed. Vol. 2. Oxford: Blackwell Textbook of dermatology, 5th ed. Vol.

3 Gorlin RJ, Sedano H, Anderson VE. The syndrome of Gorlin RJ, Sedano H, Anderson VE. The syndrome of of the teeth. F Pediatr 1964;65:895-908.

4 Hattab FN, Rawashdeh MA, Yassin M, et al. PapillonLefévre syndrome: a review of the literature and report of four cases. F Periodontol 1995;66:413-20.

5 Posteraro AF. Papillon-Lefèvre syndrome. 7 Am Dent Assoc 1992;76:16-19.

6 Haneke E. The Papillon-Lefèvre syndrome: keratosis palmoplantaris with periodontopathy. Hum Genet 1979;51: $1-35$

7 Hart TC, Shapira L. Papillon-Lefevre syndrome. Periodontology 2000 1994;6:88-100.

8 Mendieta C, Reeve CM. Periodontal manifestations of systemic disease and management of patients with systemic disease. Curr Opin Periodontol 1993:18-27. 
9 Newman M, Angel I, Karge H, et al. Bacterial studies of Papillon-Lefévre syndrome. F Dent Res 1977;56:545.

10 Clerehugh V, Drucker DB, Seymour GJ, et al. Microbiologi$\mathrm{cal}$ and serological investigations of oral lesions in PapillonLefèvre syndrome. $\mathcal{F}$ Clin Pathol 1996;49:255-7.

11 Tinanoff N, Tanzer JM, Kornman KS, et al. Treatment of the periodontal component of Papillon-Lefèvre syndrome. f Clin Periodontol 1986;13:6-10.

12 Eronat N, Ucar F, Kilinc G. Papillon-Lefevre syndrome: treatment of two cases with a clinical microbiological and histopathological investigation. f Clin Pediatr Dent 1993;17: 99-104.

13 Ishikawa I, Umeda M, Laosrisin N. Clinical, bacteriological, and immunological examinations with the treatment process of two Papillon-Lefèvre syndrome patients. F Periodontol 1994;65:364-71.

14 Rateitschak-Plüss EM, Schroeder HE. History of periodontitis in a child with Papillon-Lefèvre syndrome. f Periodontol 1984;55:35-46.

15 Bimstein E, Lustmann J, Sela MN, et al. Periodontitis associated with Papillon-Lefèvre syndrome. F Periodontol 1990 61:373-7.

16 Van Dyke TE, Taubman MA, Ebersole JL, et al. The Papillon-Lefèvre syndrome: neutrophil dysfunction with severe periodontal disease. Clin Immunol Immunopathol 1984;31:419-29.

17 D'Angelo M, Margiotta V, Ammatuna P, et al. Treatment of prepubertal periodontitis: a case report and discussion. $f$ Clin Periodontol 1992;19:214-19.

18 Summanen P, Baron EJ, Strong CA, et al. Wadsworth anaerobic bacteriology manual, 5th ed. Califonia: Star Publishing Company, 1993.

19 Holdeman LV, Cato EP, Moore WEC, eds. Anaerobe laboratory manual, 4th ed, Blacksburg, Virginia, USA: VPI Anaerobe Laboratory, 1977.

20 Tanner A, Maiden MFJ, Paster BJ, et al. The impact of 16S ribosomal RNA-based phylogeny on the taxonomy of oral bacteria. Periodontology 2000 1994;5:26-51.

21 Johnson AP. The pathogenic potential of commensal species of neisseria. F Clin Pathol 1983;36:213-23.

22 Andreesen JR. The genus eubacterium. In: Balows A Trüper HG, Dworkin M, et al, eds. The prokaryotes. A handbook on the biology of bacteria: ecophysiology, isolation, identification, applications, 2nd ed. Vol. 2. New York: SpringerVerlag, 1992:1914-24.

23 Darveau RP, Tanner A, Page RC. The microbial challenge in periodontitis. Periodontology 2000 1997;14:12-32.

24 Moore WEC, Moore LH, Ranney RR, et al. The microflora of periodontal sites showing active destructive progression. f Clin Periodontol 1991;18:729-39.

25 Uematsu $\mathrm{H}$, Hoshino E. Predominant obligate anaerobes in human periodontal pockets. F Periodontal Res 1992;27:1519.

26 Dahlén GG. Black-pigmented Gram-negative anaerobes in periodontitis. FEMS Immunol Med Microbiol 1993;6:18192.

27 Dzink JL, Socransky SS, Haffajee AD. The predominan cultivable microbiota of active and inactive lesions of cultivable microbiota of active and inactive lesions of 316-23.
28 Shah HN. The genus bacteroides and related taxa. In: Balows A, Trüper HG, Dworkin M, et al, eds. The prokaryotes. A handbook on the biology of bacteria: ecophysiology, isolation, identification, applications, 2nd ed. Vol. 4. New York: Springer-Verlag, 1992:3593-607.

29 Savitt ED, Socransky SS. Distribution of certain subgingival microbial species in selected periodontal conditions. 7 Periodontal Res 1984;19:111-23.

30 Zambon JJ, Christersson LA, Slots J. Actinobacillus actinomycetemcomitans in human periodontal disease. Prevalence in patient groups and distribution of biotypes and serotypes within families. F Periodontol 1983;54:707-11.

31 Delaney JE, Kornman KS. Microbiology of subgingival plaque from children with localized prepubertal periodontitis. Oral Microbiol Immunol 1987;2:71-6.

32 Preus H, Gjermo P. Clinical management of prepubertal periodontitis in 2 siblings with Papillon-Lefèvre syndrome. f Clin Periodontol 1987;14:156-60.

33 Schaal KP. The genera actinomyces, arcanobacterium and rothia. In: Balows A, Trüper HG, Dworkin M, et al, eds. The prokaryotes. A handbook on the biology of bacteria: ecophysiology, isolation, identification, applications, 2nd ed. Vol. 1. New York: Springer-Verlag, 1992:850-905.

34 Facklam R, Elliott JA. Identification, classification and clinical relevance of catalase-negative, Gram-positive cocci, excluding the streptococci and enterococci. Clin Microbiol Rev 1995;8:479-95.

35 Swann RA, Holmes B. Infective endocarditis caused by Kingella denitifricans. f Clin Pathol 1984;37:1384-7.

36 Chen C. Distribution of the newly described species, Kingella oralis, in the human oral cavity. Oral Microbiol Immunol 1996;11:425-7.

37 Handwerger S, Horowitz H, Coburn K, et al. Infection due to leuconostoc species: six cases and review. Rev Infect Dis 1990;12:602-10.

38 McWhinney PHM, Kibbler CC, Gillespie SH, et al. Stomatococcus mucilaginosus: an emerging pathogen in neutropenic patients. Clin Infect Dis 1992;14:641-6.

39 Spiegel CA. The genus mobiluncus. In: Balows A, Trüper HG, Dworkin M, et al, eds. The prokaryotes. A handbook on the biology of bacteria: ecophysiology, isolation, identification, applications, 2nd ed. Vol. 1. New York: Springer-Verlag, 1992:906-17.

40 Socransky SS, Haffajee AD. Bacterial etiology of destructive periodontal disease: current concepts. F Periodontol 1992; 63:322-31.

41 Velazco CH, Coelho C, Salazar F, et al. Microbiological features of Papillon-LeFèvre syndrome periodontitis. 7 Clin Periodontol 1999;26:622-27.

42 Kleinfelder JW, Topoll HH, Preus HR, et al. Microbiological and immunological findings in a patient with PapillonLefèvre syndrome. F Clin Periodontol 1996;23:1032-8.

43 Lundgren T, Renvert S, Papapanou PN, et al. Subgingival microbial profile of Papillon-Lefèvre patients assessed by DNA-probes. 7 Clin Periodontol 1998;25:624-9. 